\title{
Hormonal Profile, Antioxidant Status and Some Biochemical Parameters during Pregnancy and Periparturient Period in Dromedary She Camel
}

\author{
Howida M.A. Abd-El-Rahman*, Maha A. Ibrahim** and H. A. Elmetwaly*** \\ *Field Investigation Department, **Biology of Reproduction Department, Animal \\ Reproduction Research Institute (ARRI) and ***Camel research Department, Animal \\ Production Research Institute (APRI), Cairo, Egypt.
}

\begin{abstract}
$\mathbf{T}$ HIS STUDY aimed to determine the changes in the hormonal and biochemical profile of pregnant dromedary camels to provide a baseline data under Egyptian climatic conditions. Blood samples were collected from 15 pregnant she-camels aged 8-11 years old just postconception and thereafter monthly during gestation period and during periparturient period (at days 15, 7,4and 1prepartum, at parturition and at days 1, 4, 7 and 15 postpartum).Progesterone level increased significantly $(\mathrm{P}<0.05)$ after conception and during the $1^{\text {st }}$ and the $2^{\text {nd }}$ trimester of pregnancy then declined significantly $(\mathrm{P}<0.05)$ during the $3^{\text {rd }}$ trimester. Meanwhile its level decreased significantly $(\mathrm{P}<0.05)$ during periparturient period. Cortisol level significantly $(\mathrm{P}<0.05)$ increased at the $3^{\text {rd }}$ trimester and continued increasing significantly during prepartum period with a maximum level on the day of parturition after that it was markedly decreased during the few days postpartum to day 15 postpartum. Thyroid hormones levels were significant $(\mathrm{P}<0.05)$ decreased in their levels from early to late gestation then increased significantly $(\mathrm{P}<0.05)$ from day of parturition to day 15 postpartum. Total protein and albumin were significantly low $(\mathrm{P}<0.05)$ in the $2^{\text {nd }}$ and the $3^{\text {rd }}$ trimesters than the first one with no significance alterations in globulin levels. Total antioxidant, glutathione and ascorbic acid levels were lower in the $3^{\text {rd }}$ trimester than others, whereas the levels were relatively low in prepartum than 15 days postpartum. Malondialdehyde concentration was significantly increased $(\mathrm{P}<0.05)$ during late pregnancy period as a result of the physiological stress of pregnancy
\end{abstract}

Keywords: Hormonal, Biochemical, Antioxidants, She Camel, Pregnancy

\section{Introduction}

Pregnancy is a dynamic process characterized by dramatic physiological changes that may influence hormonal functions and biochemical values in animal. Arabian dromedary camel's reproductive physiology has received little interest, compared to studies on other domestic animals such as cattle, sheep, and goats. Literatures are scanty on the physiological and hormonal changes during pregnancy and periparturient period in she camels. Female dromedary camels' reproduction is characterized by a seasonal activity and induced ovulation [1], and exhibits follicular cycles with follicles developing and regressing successively. Progesterone hormone level in females is a very useful tool to monitor pregnancy in camels [2]. The primary source of progesterone in the female camel is the corpus luteum (CL). The placenta does not contribute to progesterone secretion, and all camelids depend entirely on progesterone from the CL to maintain their pregnancy [3].

Camel, the desert ship, is considered as one of the most adapted animals to live in the deserts. This adaptation depends on the changes in the activity of some endocrine glands, such as the thyroid which is implicated in numerous important functions. Thyroid function regulates a wide range of metabolic activities [4]. Appropriate thyroid gland function and its hormonal activity are crucial to sustain the reproductive performance, healthy pregnancy outcomes, and successful brain development in the fetus of animals [5].

Cortisol is the hormone, which is regarded as an indicator of stress in cattle [6], wildlife [7], 
pigs [8], and alpacas [9]. Cortisol plasma level was higher after transportation [9], hypoxemia in new-world camelids (N.WCs) [10] but not affected by food deprivation in the Dromedary camel [11]. So, the knowledge of some serum parameters as total protein, albumin and globulin of dromedary camels are important for assessing the physiological status and health of heavy pregnancy, parturition and postpartum periods [12].Animals are exposed to wide array of physiological and pathological stressors. In this regard, biomarkers of these conditions include assessment of both individual and total antioxidant capacity (TAC) as well as lipid peroxidation.

The periparturient or transition period defined as 3 weeks before to 3 weeks after parturition, is characterized by marked changes in animal's endocrine status that is much more dramatic than any other time in the lactation-gestation cycle. In female Dromedary camels, the physiology of the periparturient period has gained little attention and most of the available data describing metabolism during the transition phase was based only on a few measurements $[13,14]$.

The purpose of this study is to provide a baseline data on the one humped pregnant camel under Egyptian climatic conditions. It will determine the physiological changes in the hormonal profile and serum clinical biochemistry analyses because the results of some parameters for pregnant camels do not fall in the range of non-pregnant camels, and hence comparing these findings with those of non-pregnant camels and other reported animals as cattle for example is not accurate.

\section{Material and Methods}

The present study was conducted in Animal Production Research Institute (APRI) camel farm at Mattrouh governorate and Animal Production Research Institute (ARRI). The present work aimed to investigate the hormonal profile and biochemical parameters during pregnancy and periparturient period (prior to parturition, at time of parturition, and postpartum period) such as (total estrogens, progesterone and cortisol), thyroid hormones $\left(\mathrm{T}_{3}\right.$ and $\left.\mathrm{T}_{4}\right)$ levels as well as (total protein, albumin and globulin), total antioxidant capacity (TAC) and lipid peroxidation.

\section{Animals}

A total of 15 apparently healthy and free from parasitic infestation dromedary she camels aged between 8 and 11 years old and weighing about $500 \mathrm{~kg}$ were used in this experiment. Spontaneous Egypt. J. Vet. Sci. Vol. 48, No.2 (2017) parturitions were controlled by the veterinarian. All camels delivered vital calves and puerperium was physiological. Colostrum and milk showed no sensory changes, none of the camels had mastitis.

\section{Feeding}

Experimental she camels were fed diet composed mainly of commercial concentrates mixture (12\%crude protein and 70\% TDN) $(4.5 \mathrm{~kg} /$ head/day)in addition to a good quality roughage material that were alfalfa hay in summer and Egyptian green alfalfa in winter $(16 \mathrm{~kg} / \mathrm{head} / \mathrm{day})$. All animals had a free access to drinking water.

\section{Blood sampling}

Blood sampling was startup just postconception, and thereafter monthly during gestation period (early, mid, and late pregnancy) and during periparturient period (at days 15, 7, 4 and 1 prepartum at parturition, and at days 1, 4, 7 and 15 postpartum). Ten $\mathrm{ml}$ blood were collected biweekly individually from the jugular vein of all females in the experiment in the morning before feeding. Blood samples were placed on ice during collection and stored at $4^{\circ} \mathrm{C}$ for 6 hours, and then serum was separated by centrifugation at $3000 \mathrm{rpm}$ for 20 minutes and stored at $-20^{\circ} \mathrm{C}$ till analyses.

All hormones were assayed using ELISA micro wells kits (Monobind Inc. Lakeforest, CA92630.USA): progesterone $\left(\mathrm{P}_{4}\right)$ [15], estradiol (E17ß) [16], total triiodothyronine [17], total thyroxin [18], Cortisol [19].

Blood samples were analyzed calorimetrically by commercial kits for: total protein and albumin [20]. Globulin level was calculated by subtraction of albumin content from the total protein value also. Also, total antioxidant capacity (TAC) [21], ascorbic acid (Vit c) [22], Glutathione-S- transferase (GST) [23], free radicals (malondialdehyde MDA) [24].

\section{Statistical analysis}

All data were subjected to statistical analysis according to Snedecor and Cochran [25] and results were expressed as Means \pm standard error (SE). Differences between means in different groups were tested for significance using student $\mathrm{T}$ test as independent $\mathrm{t}$ test for all parameters.

\section{Results and Discussions}

Serum progesterone, estradiol-17 $\beta$, cortisol, $\mathrm{T}_{3}$, and $\mathrm{T}_{4}$ results during pregnancy are presented in Table1.In this study, serum progesterone concentrations in pregnant camels started to 
increase after successful mating to reach (5.5 $\mathrm{ng} / \mathrm{ml}$ ) during the first trimester of pregnancy, the concentration during the second trimester was $(7.3 \mathrm{ng} / \mathrm{ml})$ significantly $(\mathrm{P}<0.05)$ higher than that of the first trimester and then declined significantly to reach $(6.15 \mathrm{ng} / \mathrm{ml})$ during the third trimester (Table 1).These results are agree with [26-29] which showed that the progesterone levels during gestation increased gradually from early to late gestation and the drop in its levels only noted at end of gestation or prior to parturition. In she camels, serum progesterone concentrations are constantly low [30], and its concentration starts to rise after mating. Following mating, at least one corpus luteum is formed that secretes a significant amount of progesterone. Camels evidencing serum progesterone profiles above 2.0 and $3.0 \mathrm{ng} / \mathrm{ml}$ at 20 and 30 day of mating should be considered pregnant [31]. The difference in progesterone levels between stages of gestation were significant but not sharp. It seems that absence of sharp variation in progesterone level during gestation in she camel may confirm that the main source of progesterone throughout their pregnancy is from corpus luteum [32] and not from placenta as usually reported in other species. Results of the present study indicated that the periparturient period had a high significant effect $(\mathrm{P}<0.05)$ on serum progesterone levels in dromedaries she camel (Fig. 1). On day 15 prepartum serum progesterone level was $4.02 \mathrm{ng}$ / $\mathrm{ml}$ followed by a reduction to $3.16 \mathrm{ng} / \mathrm{ml}$ on day 7 and $3.44 \mathrm{ng} / \mathrm{ml}$ on day 4 till reached $2.12 \mathrm{ng} / \mathrm{ml}$ on day 1prepartum.On the day of parturition serum progesterone level reach $1.9 \mathrm{ng} / \mathrm{ml}$ and continued in reduction thereafter till reach $1.32 \mathrm{ng} / \mathrm{ml}$ on day 15 postpartum. These results showed that serum activity of progesterone decreased sharply at parturition and thereafter, this decline in progesterone activity at parturitionis physiological and was also reported by El-Mougy and Elias et al. $[33,26]$, it seems that this characteristic drop of progesterone at parturition may be due to the destruction of the corpus luteum of pregnancy as a sequel of luteolysis.

This study indicated an increase in serum estradiol level at late gestation, and achieved its peak during third trimester (Table1). The overall means value of estradiol in pregnant camels at $1^{\text {st }}$, $2^{\text {nd }}$ and $3^{\text {rd }}$ trimesters were $17.60 \pm 0.28,23.50 \pm$ 0.38 and $160.9 \pm 3.54 \mathrm{pg} / \mathrm{ml}$, respectively. These results are agreed with Mohamed and Hassan et al. [34, 35]. Estrogens are continuously secreted during pregnancy in she-camel [28], and their concentrations rise at mid-gestation, suggesting continued follicular development during pregnancy $[36,37]$.

Fig. 2 shows serum estradiol levels during periparturient period. Serum estradiol levels increased significantly $(\mathrm{P}<0.05)$ on days 15 , 7and 4 prepartum $(231.4,288.6$ and $407.6 \mathrm{pg} / \mathrm{ml})$, respectively. But its level decreased significantly $(\mathrm{P}<0.05)$ to reach $(212.7 \mathrm{pg} / \mathrm{ml})$ on day 1 prepartum and $(128.2 \mathrm{pg} / \mathrm{ml})$ on day of parturition, after that it continued decreasing significantly on days 1 , 4,7 and 15 post- partum to reach $(73.4,47.6,36.5$ and $14.5 \mathrm{pg} / \mathrm{ml}$ ), respectively.

Our obtained results showed an increase in estradiol levels towards the end of pregnancy (last two months) with a maximum level 4 days prior to parturition and then declined sharply one day before and during the act of parturition, with a consistent decline in estradiol profiles during the few days postpartum up to day 15 . These results were agreed with Hassan et al. [35] who stated that estradiol levels diminish 24 hours prior to parturition. The rapid rise in estradiol during the $3^{\text {rd }}$ trimester (late gestation) probably originates from placenta and this belief was supported by [33, 32]. The maternal estradiol dropping following parturition indicating that the estradiol measured

TABLE 1. Hormonal profiles during pregnancy in she camels.

\begin{tabular}{|c|c|c|c|}
\hline \multirow{2}{*}{ Parameter } & \multicolumn{3}{|c|}{ Trimesters of pregnancy } \\
\hline & $1^{\text {st }}$ trimester & $2^{\text {nd }}$ trimester & $3^{\text {rd }}$ trimester \\
\hline Progesterone (ng/ml) & $5.50 \pm 0.08^{\mathrm{c}}$ & $7.30 \pm 0.23^{a}$ & $6.150 \pm 0.15^{b}$ \\
\hline Estradiol (pg/ml) & $17.60 \pm 0.28^{b}$ & $23.50 \pm 0.38^{b}$ & $160.9 \pm 3.54^{\mathrm{a}}$ \\
\hline $\mathrm{T}_{3}(\mathrm{ng} / \mathrm{ml})$ & $2.20 \pm 0.15^{\mathrm{a}}$ & $1.70 \pm 0.08^{b}$ & $1.90 \pm 0.04^{\mathrm{b}}$ \\
\hline $\mathrm{T}_{4}(\mu \mathrm{g} / \mathrm{dl})$ & $15.24 \pm 0.41^{\mathrm{a}}$ & $13.20 \pm 0.46^{b}$ & $14.3 \pm 0.44^{\mathrm{ab}}$ \\
\hline
\end{tabular}

Means \pm Standard Error with different superscripts (a,b, c) in the same row, are significantly different at $\mathrm{P}<0.05$. 
in pregnant she camels was fetoplacental in origin. In sheep the placenta at term possesses an active steroid $17 \alpha$ hydroxylase system [38] and it able to convert $17 \alpha$ hydroxyl progesterone to estrogen [39].A similar situation may exist in camel during the final months of pregnancy as observed by Elias et al. [33] who found a high concentration of estradiol (241- $390 \mathrm{pg} / \mathrm{ml})$ in allantoic fluid of she camel at birth. It could be possible to say that the high prepartum estrogen played an important role in initiation of oxytocin release and uterine contractions needed for fetal expulsion during parturition [40,41].It is also evident in this work that estradiol characteristic increase at the last 2 months of gestation coincided with serum progesterone decrease, this finding is in agreement with that reported by Elias et al and El-Mougy et al. $[33,26]$, it seems that this characteristic drop of progesterone at parturition which is a sequel of luteolysis and increase in estradiol level at 2 weeks prepartum are needed for the expulsion of the fetus which is preceded by the attainment of a minimum level of plasma progesterone and high levels of estrogen [33].

Serum cortisol level showed a constant pattern from early to mid-gestation and a fast increase from mid to late gestation. The increase from mid to late gestation was significantly $(\mathrm{P}<0.05)$ high and sharp (Table1). During the periparturient period there was a significant $(\mathrm{P}<0.5)$ increase in serum cortisol level began from day 15 to day 1 prepartum with a maximum level at the day of parturition that was $117.68 \mathrm{ng} / \mathrm{ml}$, after that it was a markedly decreased during the few days postpartum to reach $11.3 \mathrm{ng} / \mathrm{ml}$ on day 15 postpartum (Fig. 3).

In our findings, significantly higher values of

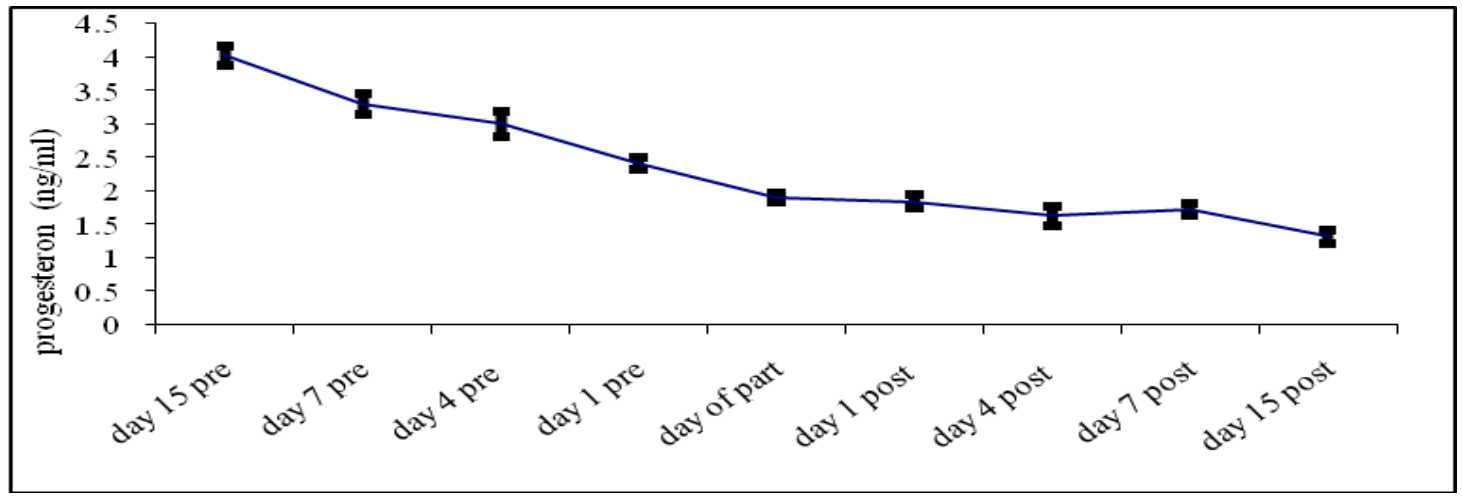

Fig.1. Mean serum progesterone concentrations $( \pm \mathrm{SE})$ of pregnant she camel around parturition $($ pre $=$ prepartum, post=postpartum, day of part=day of parturition).

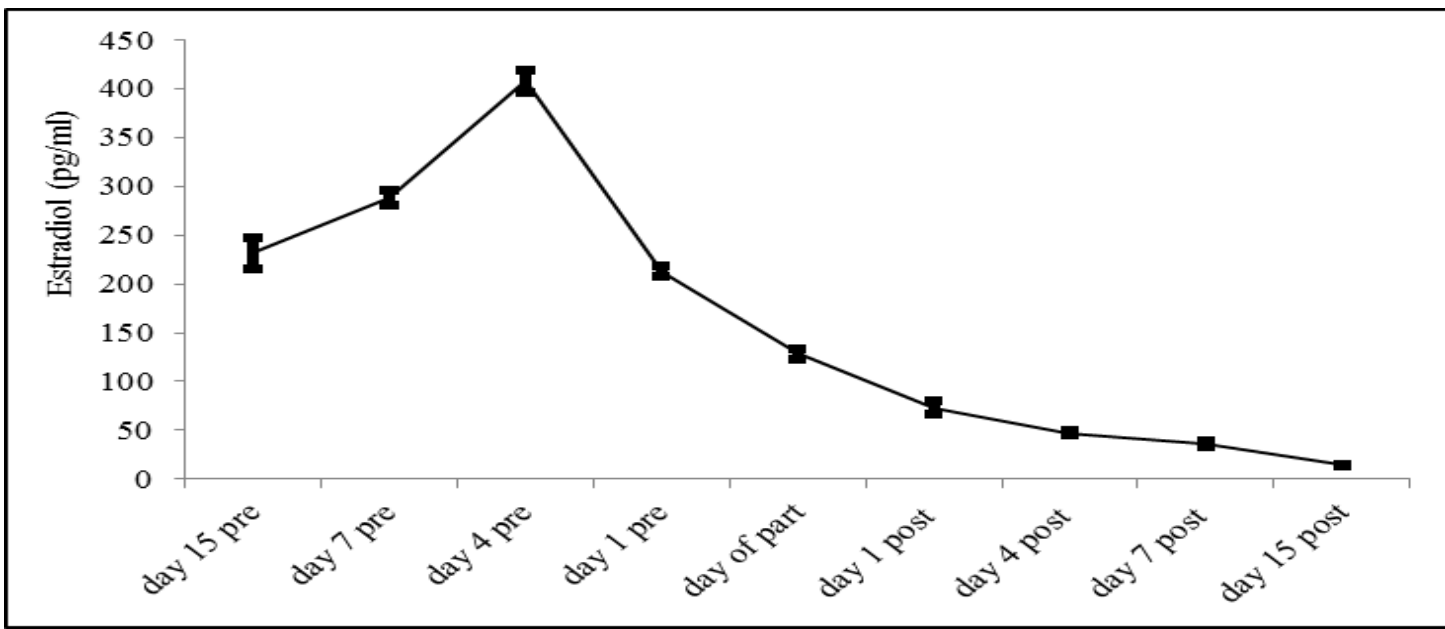

Fig.2. Mean serum estradiol concentrations $( \pm \mathrm{SE})$ of pregnant she camels around parturition $($ pre $=$ prepartum, post=postpartum, day of part=day of parturition).

Egypt. J. Vet. Sci. Vol. 48, No.2 (2017) 


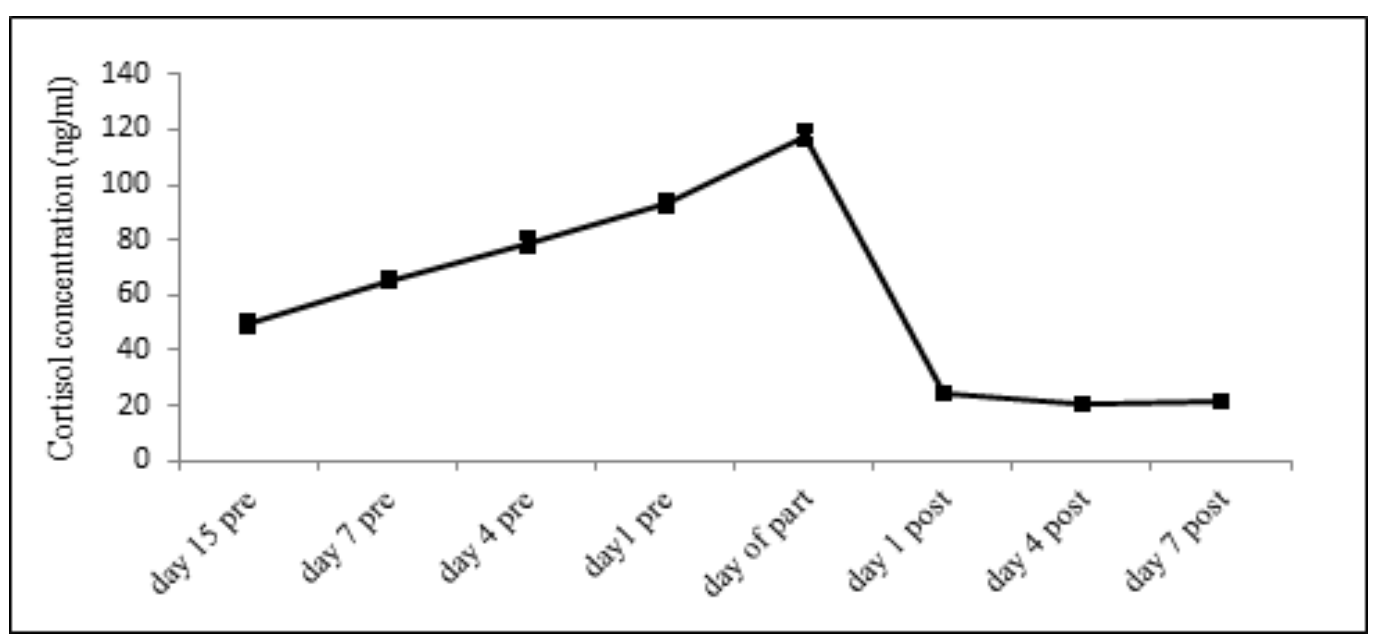

Fig. 3. Mean serum cortisol concentrations $( \pm \mathrm{SE})$ of pregnant she camel around parturition (pre $=$ prepartum, post=postpartum, day of part=day of parturition).

serum cortisol were seen in she camels during late pregnancy that were agreed with the results of Habeeb et al. [42] Who found that the highest level of cortisol was detected at late pregnancy in female Dromedary camels. During the late stage of pregnancy, there was an increase in the ACTH secretion from the fetal pituitary which stimulates the rapid growth of the fetal adrenals, leading to a rise in the concentration of serum cortisol. The increased cortisol enters the maternal circulation rise the maternal serum cortisol level. Cortisol from the fetus stimulates estrogen production by the placenta, [43]. The placental estrogen stimulates uterine secretion of the luteolytic factor, prostaglandin $\mathrm{F}_{2} \alpha(\mathrm{PGF} 2 \alpha)[44,45,46]$, which interrupts progesterone secretion. The hormonal environment of the dam stimulates dilation of the cervix (which permits the fetus to pass through the birth canal) and uterine contractions (which expel both the fetus and placental membranes). Therefore, a combination of hormones from the fetus, placenta and dam induce a series of events leading to parturition [43]. Exogenous glucocorticoid administered to the mother can be used to induce parturition in cow, sheep and goat [47]. Likewise glucocorticoid can induce parturition in buffalo [48] and camel. Also, the high cortisol level in late pregnancy means that the pregnant female was under stress during this period and ended after calving.

In addition, cortisol is important for surface and formation of the fetal lung to prevent hyaline membrane disease that ends in respiratory failure. Moreover, cortisol is an immune-suppressive hormone that abolishes the immunological response against the fetus, consequently saving the fetal life. Cortisol also, induced gluconeogenesis that provide adequate glucose supplement necessary for the fetal nutrition [49].

The results showed that serum estrogen and cortisol levels have increased sharply before parturition and coincided with a decline in serum $\mathrm{P}_{4}$ level that might confirm their role in triggering parturition in she camel. It could be concluded that together with other parameters, estradiol$17 \mathrm{~B}$, progesterone and cortisol may be used as good indicators to predict the time of parturition in she-camel. Cortisol may be used as good indicators to predict the time of parturition in she-camel, before decreasing thereafter.

The trail stated that there was a marked variation in serum thyroid hormones level from early to late gestation. There were a significant $(\mathrm{P}<0.05)$ decrease from first to second trimester and there was a slight increase in their levels from second to third trimester this slight increase was significant $(\mathrm{P}<0.05)$ in $_{4}$ and non-significant in $_{3}$ levels. Our findings are in agreement with [50] who found that free thyroid hormones levels remain unchanged or decreased in pregnancy. The overall means value of $\mathrm{T}_{3}$ and $\mathrm{T}_{4}$ in pregnant camels at $1^{\text {st }}, 2^{\text {nd }}$ and $3^{\text {rd }}$ trimesters were $(2.20$ $\pm 0.15,1.70 \pm 0.08$ and $1.90 \pm \cdot, \cdot \varepsilon \mathrm{ng} / \mathrm{ml})$ and $(15.24 \pm 0.41,13.20 \pm 0.46$ and $14.3 \pm 0.44 \mu \mathrm{g} /$ dl), respectively.

Thyroid function regulates a wide range of metabolic activities [4] and significantly affects lipoprotein metabolism [51]. Appropriate thyroid gland function and its hormonal activity are crucial to sustain the reproductive performance, 
healthy pregnancy outcomes, and successful brain development in the fetus of animals [5].

Reduction in total circulating thyroid hormones during pregnancy could be due to the increase of turnover rate or the decrease in the secretion of the hormones from the thyroid gland. During pregnancy, hepatocytes increase their production of thyroid-binding globulin (TBG). High TBG and high estradiol concentration during pregnancy induced a reduction in free circulating hormones such as thyroxin [52]. Estrogens can alter the secretion rate and dynamics of thyroid hormones. It seems that fluctuations in thyroid activity might be due to the interactions with varying concentrations of estrogens and progesterone during the pregnancy of camels [53].

On the other hand, our results indicated that during prepartum period there was no changes in serum thyroid hormones levels in pregnant she camel, meanwhile during postpartum period there were a significant changes on their levels beginning from day one (Fig. 3, 4).On day of parturition $\mathrm{T}_{3}$ was $(1.92 \pm 0.26 \mathrm{ng} / \mathrm{ml})$ and $\mathrm{T}_{4}$ was $(13.7 \pm 0.37 \mu \mathrm{g} /$ dl) followed by a significant $(\mathrm{P}<0.05)$ increase in their levels to reach $(2.18 \pm 0.18,2.67 \pm 0.23$, $2.46 \pm 0.09$ and $2.64 \pm 0.14 \mathrm{ng} / \mathrm{ml})$ and $(16.48 \pm 0.31$, $15.94 \pm 0.20,16.84 \pm 0.32$ and $17.28 \pm 0.27 \mu \mathrm{g} / \mathrm{dl})$ at day 1 , day 4 , day 7 and day 15 postpartum for $\mathrm{T}_{3}$ and $\mathrm{T}_{4}$, respectively.

Increase in postpartum serum triiodotheronine levels as compared with prepartum levels might be due to the increase in metabolic rate after calving as an anabolic process to rebuild destructive tissues and to compensate the deficiency of blood metabolites which could be occurred during pregnancy [54].

Serum total protein, albumin and globulin during pregnancy are presented in Table 2 . Serum levels of total protein and albumin were significantly low $(\mathrm{P}<0.05)$ in the $2^{\text {nd }}$ and $3^{\text {rd }}$ trimesters than the first one as follow, total protein were $(6.40 .11 \pm 6.1,0.13 \pm$ and $5.70 .16 \pm$ $\mathrm{g} / \mathrm{dl})$, albumin were $(3.10 .09 \pm 2.7,0.14 \pm$ and $2.220 .07 \pm \mathrm{g} / \mathrm{dl})$ and the globulin levels were not significantly changed $(\mathrm{P}<0.05)(3.3,0.10 \pm$ $0.15 \pm 3.4$ and $3.50 .21 \pm \mathrm{g} / \mathrm{dl})$ respectively.

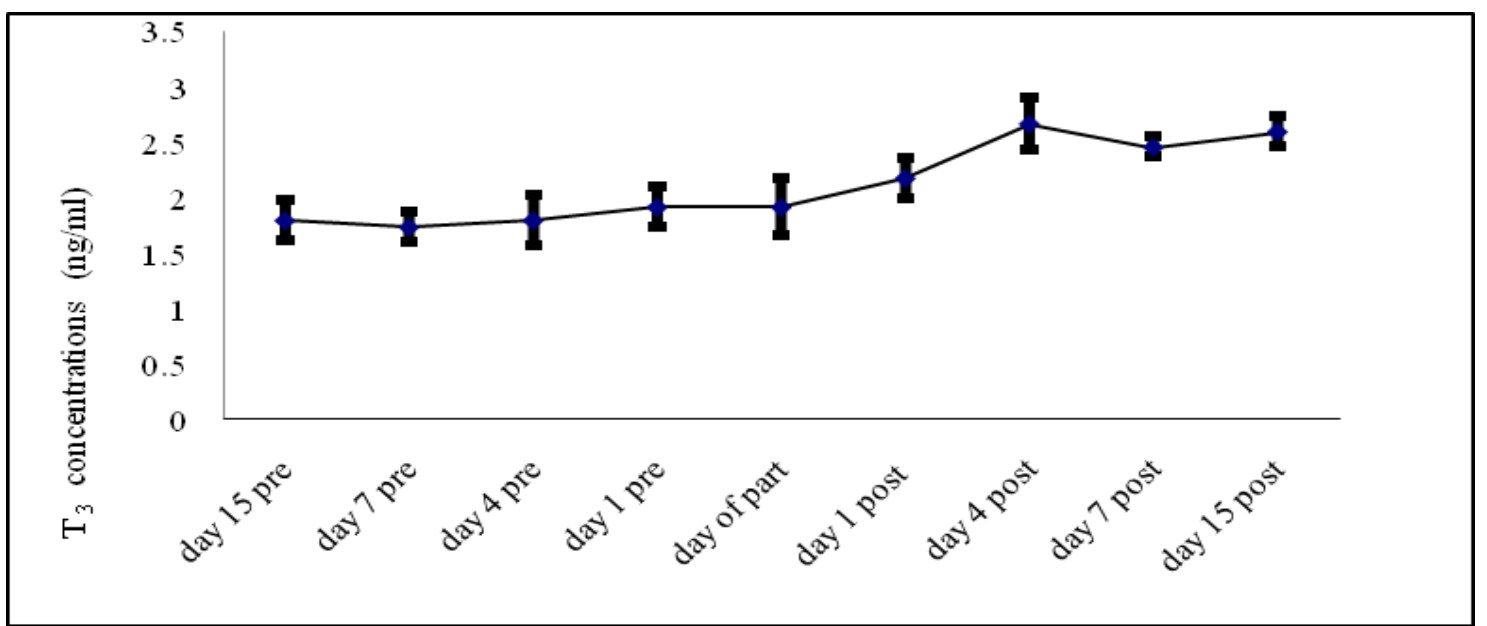

Fig. 4. Mean serum triiodothyronine (T3) concentrations $( \pm$ SE) of pregnant she camels around parturition $($ pre $=$ prepartum, post=postpartum, day of part=day ofparturition).

TABLE 2. Serum total protein, albumin and globulin levels during pregnancy in she camels.

\begin{tabular}{lccc}
\hline \multirow{2}{*}{ Parameter } & \multicolumn{3}{c}{ Trimesters of pregnancy } \\
\cline { 2 - 4 } & $\mathbf{1}^{\text {st }}$ trimester & $\mathbf{2}^{\text {nd }}$ trimester & $\mathbf{3}^{\text {rd }}$ trimester \\
\hline Total protein $(\mathrm{g} / \mathrm{dl})$ & $6.4 \pm 0.13^{\mathrm{a}}$ & $6.1 \pm 0.11^{\mathrm{ab}}$ & $5.7 \pm 0.16^{\mathrm{b}}$ \\
Albumin $(\mathrm{g} / \mathrm{dl})$ & $3.3 \pm 0.14^{\mathrm{a}}$ & $2.7 \pm 0.08^{\mathrm{b}}$ & $2.5 \pm 0.07^{\mathrm{c}}$ \\
Globulin $(\mathrm{g} / \mathrm{dl})$ & $3.1 \pm 0.14^{\mathrm{a}}$ & $3.3 \pm 0.10^{\mathrm{a}}$ & $3.3 \pm 0.21^{\mathrm{a}}$ \\
\hline Mean \pm Standard Error with different superscripts $(\mathrm{a}, \mathrm{b}, \mathrm{c})$ in the same row, are significantly different at $\mathrm{P}<0.05(\mathrm{LSD})$.
\end{tabular}

Mean \pm Standard Error with different superscripts $(a, b, c)$ in the same row, are significantly different at $\mathrm{P}<0.05$ (LSD).

Egypt. J. Vet. Sci. Vol. 48, No.2 (2017) 


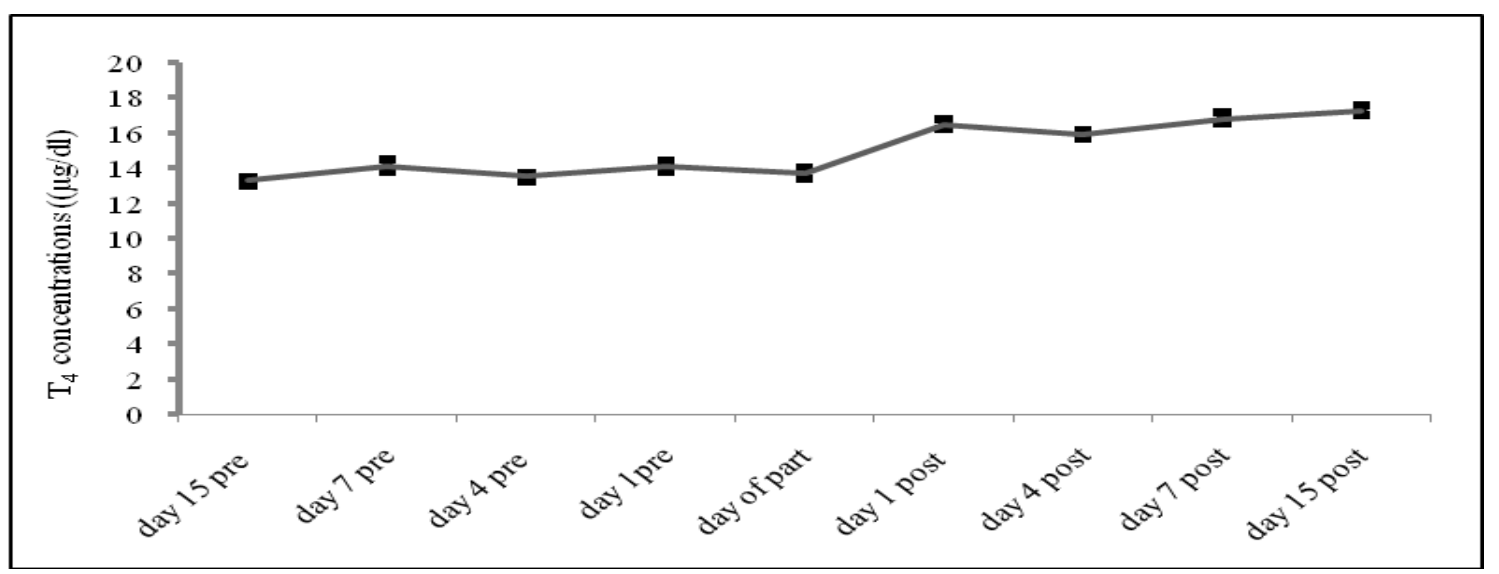

Fig. 5. Mean serum thyroxin $\left(\mathrm{T}_{4}\right)$ concentrations $( \pm \mathrm{SE})$ of pregnant she camels around parturition $($ pre $=$ prepartum, post=postpartum, day of part=day of parturition).

Also, the results around parturition in (Figs 6,7 and 8) showed significant $(\mathrm{P}<0.05)$ decrease in total protein, albumin and globulin from day 15 prepartum till day of parturition then gradual increase till day 15 postpartum.

Regarding serum total protein profile, the decrease in its level at term or prior to parturition had also been reported in cows [55-57], ewes [58], and goats [59]. In our findings, significantly lower values of serum albumin were seen in pregnant she camels that were agreed with the results of Hang-Poung [60]. Also, Saleh et al. [61] reported a negative correlation between the level of serum proteins and pregnancy in Holstein cows. The decrease in serum total protein as parturition approaches may be attributed to the fact that the fetus synthesizes all of its proteins from the amino acids that derived from the dam, and the fetus growth increases exponentially reaching a maximum level, especially in muscles, during late pregnancy [62].

Serum globulin showed no significant alterations around parturition, this result disagreed with most findings as Janku et al. [63] because this period could be associated mainly with the production of colostrum and other immunological changes typical for the periparturient period but this observation agreed with Saleh et al. [61]. The change of total protein, albumin and globulin may be due to the transfer of albumin and $\gamma$-globulins and total protein from blood to the mammary glands [64]. In contrast to our results and the findings of Hang-Poung[60] and El-Tohamy et al. [65] reported that protein concentration increases with the advancement of pregnancy.

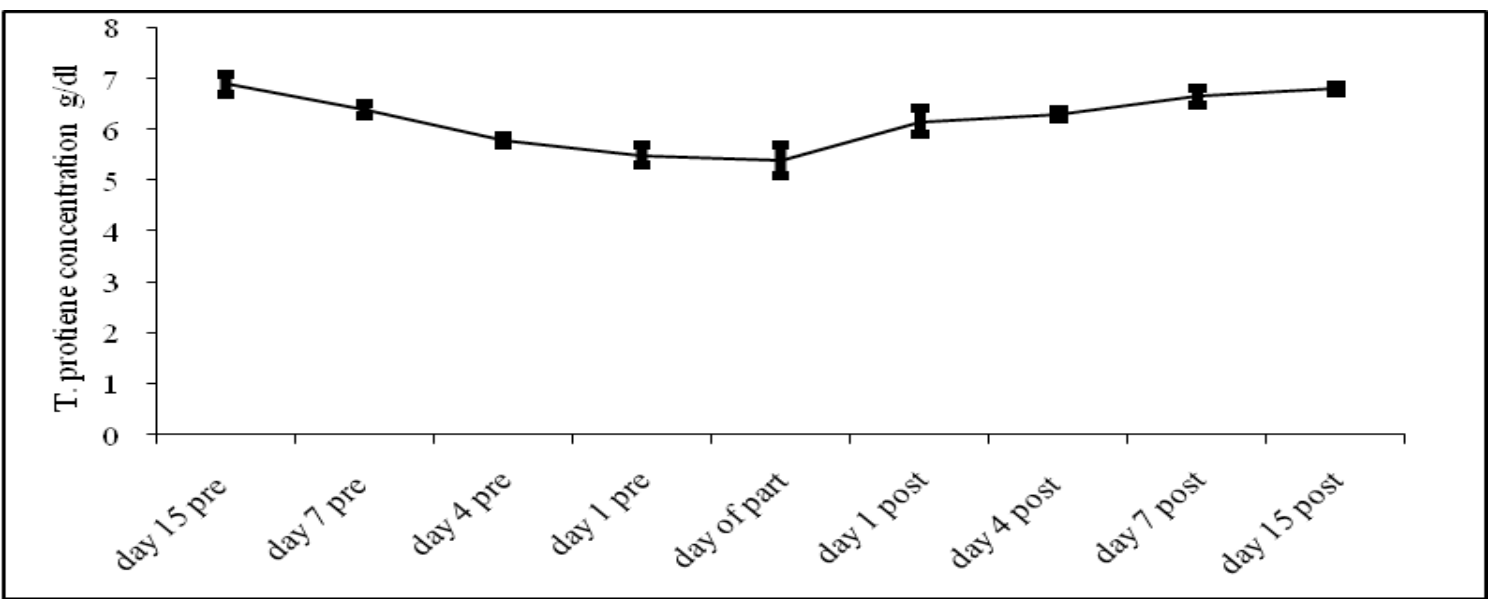

Fig. 6. Mean serum T. protein concentrations $( \pm \mathrm{SE})$ of pregnant she camels around parturition $($ pre $=$ prepartum, post=postpartum, day of part=day of parturition). 


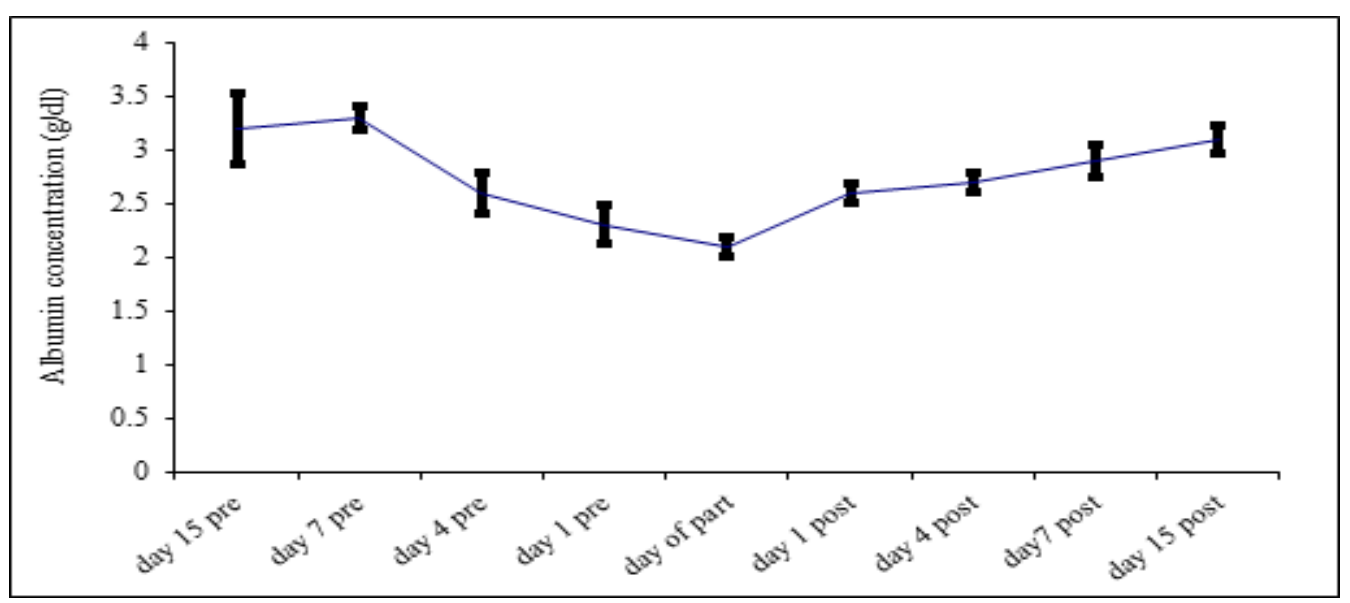

Fig.7. Mean serum Albumin concentrations $( \pm \mathrm{SE})$ of pregnant she camels around parturition (pre $=$ prepartum, post=postpartum, day of part=day of parturition).

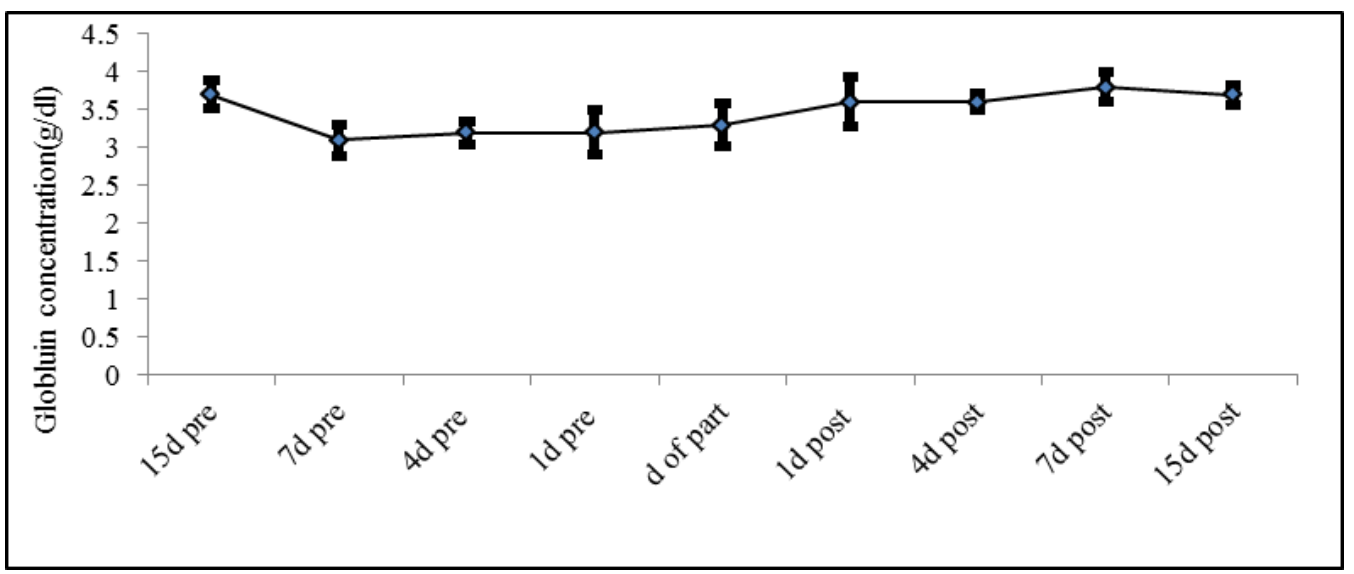

Fig. 8. Mean serum Globulin concentrations $( \pm$ SE) of pregnant she camels around parturition (pre $=$ prepartum, post=postpartum, day of part=day of parturition).

Table 3, results presented in $1^{\text {st }}$ trimester, 2 nd and $3^{\text {rd }}$ trimesters of pregnancy, the total antioxidants capacity were $(0.55 \pm 0.007,0.53 \pm 0.007$ and $0.42 \pm 0.008)$, glutathione serum levels $(5.80 \pm 0.05,5.50 \pm 0.08$ and $4.90 \pm 0.08)$ and ascorbic acid levels $(6.30 \pm 0.10,5.40$ \pm 0.11 and $3.9 \pm 0.08)$ respectively. The results revealed that the total antioxidant capacity, glutathione and ascorbic acid levels were lower significantly $(\mathrm{P}<0.05)$ in $3^{\text {rd }}$ trimester than $1^{\text {st }}$ and $2^{\text {nd }}$ trimesters of pregnancy, whereas the levels were relatively low in prepartum than 15 days postpartum.

TABLE 3. Serum Total Antioxidant, Glutathione, Vitamin C and MDA.
In the present findings, the low values of total antioxidant could be linked to the adaptive capacity, in order to optimize the consumption of oxygen and neutralization of free radicals. Also, Brzezinska et al. [66] reported a decrease in total antioxidants with approaching parturition in cows. The values started increasing after parturition and reached normal range 30 days post-parturition [67]. On the other hand, [68]disagreed with our investigations and reported that plasma total antioxidants activity did not vary among different

\begin{tabular}{lccc}
\hline \multirow{2}{*}{ Parameter } & \multicolumn{3}{c}{ Trimesters of pregnancy } \\
\cline { 2 - 4 } & $\mathbf{1}^{\text {st }}$ trimester & $\mathbf{2}^{\text {nd }}$ trimester & $\mathbf{3}^{\text {rd }}$ trimester $^{\mathrm{a}}$ \\
\hline Total antioxidant $(\mathrm{m} / \mathrm{L})$ & $0.55 \pm 0.007^{\mathrm{a}}$ & $0.53 \pm 0.007^{\mathrm{a}}$ & $0.42 \pm 0.008^{\mathrm{b}}$ \\
Glutathione $(\mathrm{nmol} / \mathrm{ml})$ & $5.80 \pm 0.05^{\mathrm{a}}$ & $5.50 \pm 0.08^{\mathrm{b}}$ & $4.90 \pm 0.08^{\mathrm{c}}$ \\
Vitamin C $(\mathrm{mg} / \mathrm{L})$ & $6.30 \pm 0.10^{\mathrm{a}}$ & $5.40 \pm 0.11^{\mathrm{b}}$ & $3.90 \pm 0.08^{\mathrm{c}}$ \\
MDA $(\mathrm{nmol} / \mathrm{ml})$ & $22.4 \pm 0.39^{\mathrm{C}}$ & $28.6 \pm 0.28^{\mathrm{b}}$ & $36.6 \pm 0.08^{\mathrm{a}}$ \\
\hline
\end{tabular}

Mean \pm Standard Error with different superscripts (a, b, c) in the same row, are significantly different at $\mathrm{P}<0.05$.

Egypt. J. Vet. Sci. Vol. 48, No.2 (2017) 
treatment groups at 60 days before calving and continued to decline from 30 days prepartum till calving.

Serum GSH levels were significantly $(\mathrm{P}<0.05)$ lower in late pregnancy and increased gradually till early lactation. That may be due to the activity of blood GSH that was increased with the increased lipid peroxidation, while GSH activity had a negative correlation with MDA production
[69]. Therefore, an imbalance between increased production of ROS and reduced availability of antioxidant defense near parturition might increase oxidative stress and may contribute to periparturient disorders in dairy cows [70]. A relationship between the physiological changes associated with parturition and a loss in overall antioxidant potential was established in both humans and dairy cows [71,72].

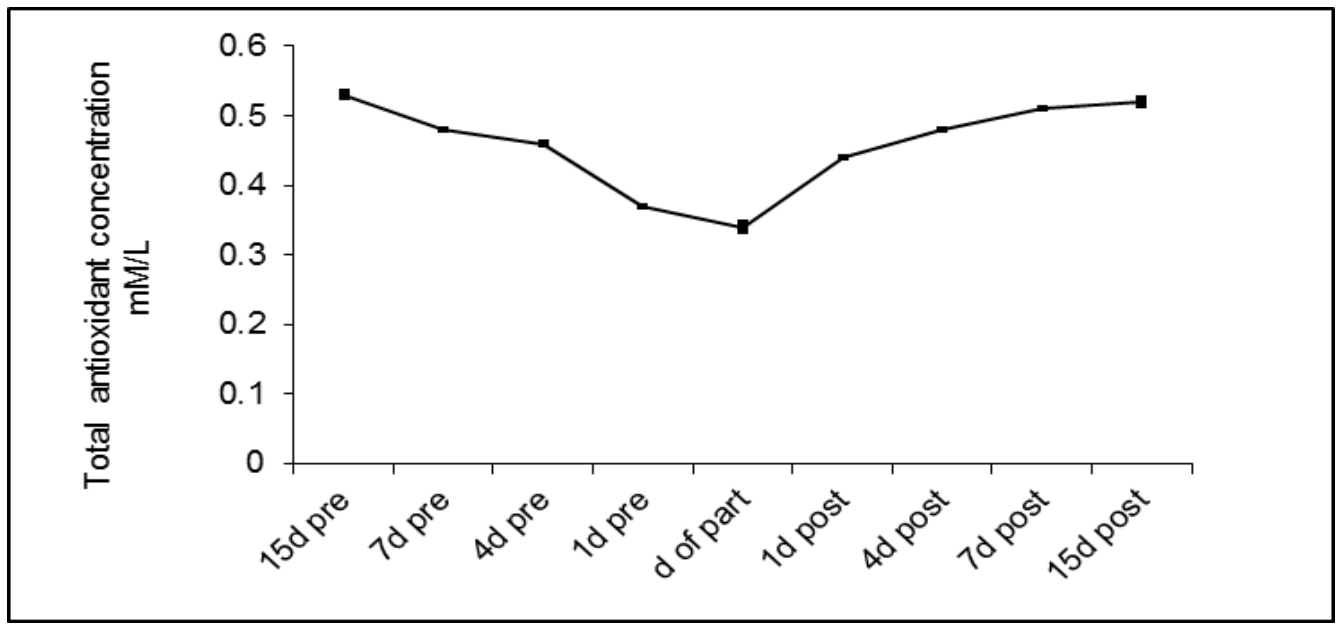

Fig. 9. Mean serum T.antioxidant concentrations $( \pm$ SE) of pregnant she camels around parturition $($ pre $=$ prepartum, post=postpartum, day of part=day of parturition).

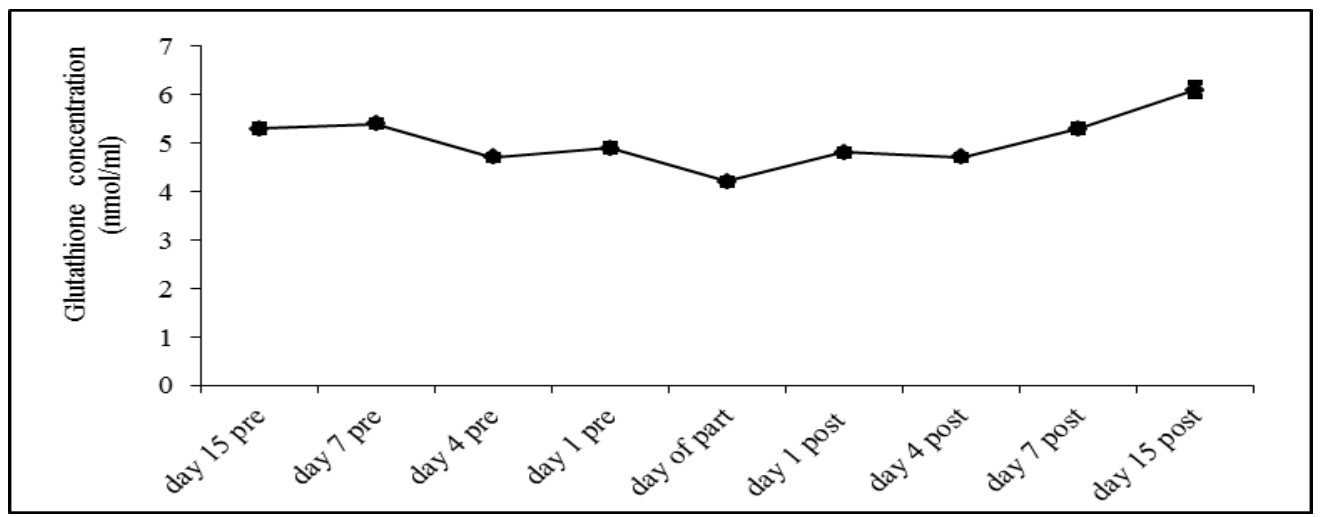

Fig.10. Mean serum Glutathione concentrations $( \pm \mathrm{SE})$ of pregnant she camels around parturition $($ pre $=$ prepartum, post=postpartum, day of part=day of parturition).

Also, our results agreed with Hasab et al. [73] who reported that ascorbic acid is produced from glucose and it could be suggested that glucose availability was limiting ascorbic acid synthesis during pregnancy. However, there was no clear association between ascorbic acid status and the glucose level. In lactating she camels, high plasma ascorbic acid was associated with low glucose. During lactation, here is an extra need for glucose to serve as a precursor for lactose synthesis, which is reflected by low plasma glucose. In cattle, at different stages of estrus and pregnancy, Miszkiel et al. [74] found that ascorbic acid concentrations were directly correlated with those of progesterone, she camels in estrus were found to have increased ascorbic acid levels in plasma and total leukocytic count. In contrast to our findings, Naziroğlu and Gür [75] did not find any difference between pregnant and non- pregnant cows with respect to plasma ascorbic acid. 


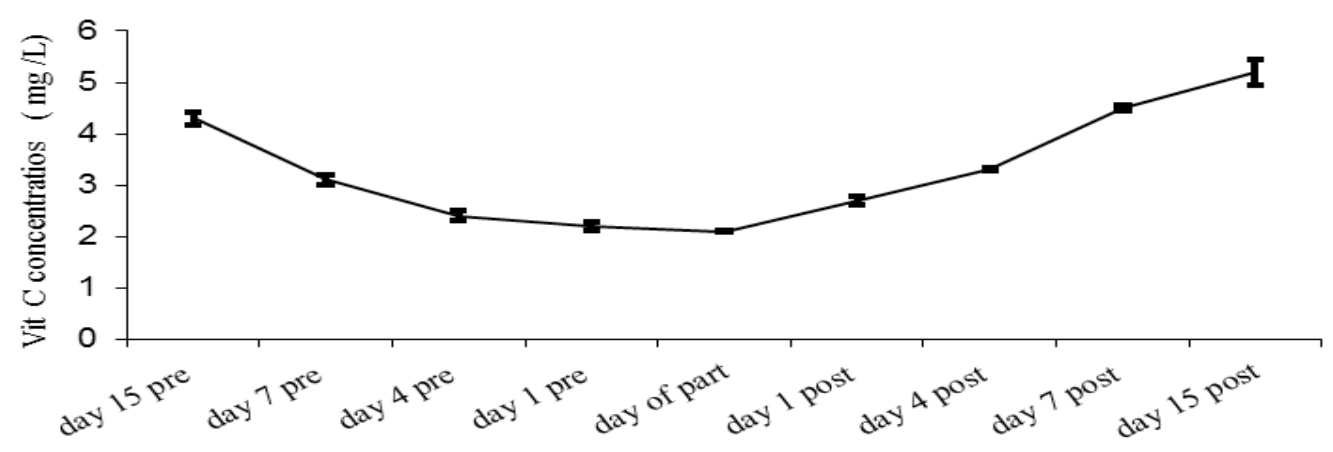

Fig. 11. Mean serum Vitamin $C$ concentrations $( \pm S E)$ of pregnant she camels around parturition (pre $=$ prepartum, post=postpartum, day of part=day of parturition).

Table 3 and Fig.12, also show the level of MDA in pregnant female camels in different pregnancy trimesters and around parturition period respectively, MDA concentration was significantly increased $(\mathrm{P}<0.05)$ during $3^{\text {rd }}$ trimester of pregnancy period $(36.6 \pm 0.08)$, it is clear that lipid peroxidation occurs naturally in cells therefore free radicals production also considered as a normal physiological process but increased free radicals production during pregnancy may be due to the stressful condition of pregnancy which leads to many metabolic and physiological changes including increasing of the basal metabolic rate during pregnancy [76]. This increase in free radical leads to increase oxidative stress due to increase lipid peroxidation [77]. The measurement of end products of lipid peroxidation is the best method to estimate free radicals level in samples because free radicals have a very short half-life [78], therefore, the effects of free radicals was estimated by estimating its stable end products, MDA [79].

\section{Conclusion}

The present study bring knowledge on the values of hormonal, biochemical and antioxidants serum parameters in healthy pregnant and periparturient Dromedary camels. Such values are necessary not only for diagnostic interpretation of pathological findings in animals, but also for their utilization in the experimental studies.

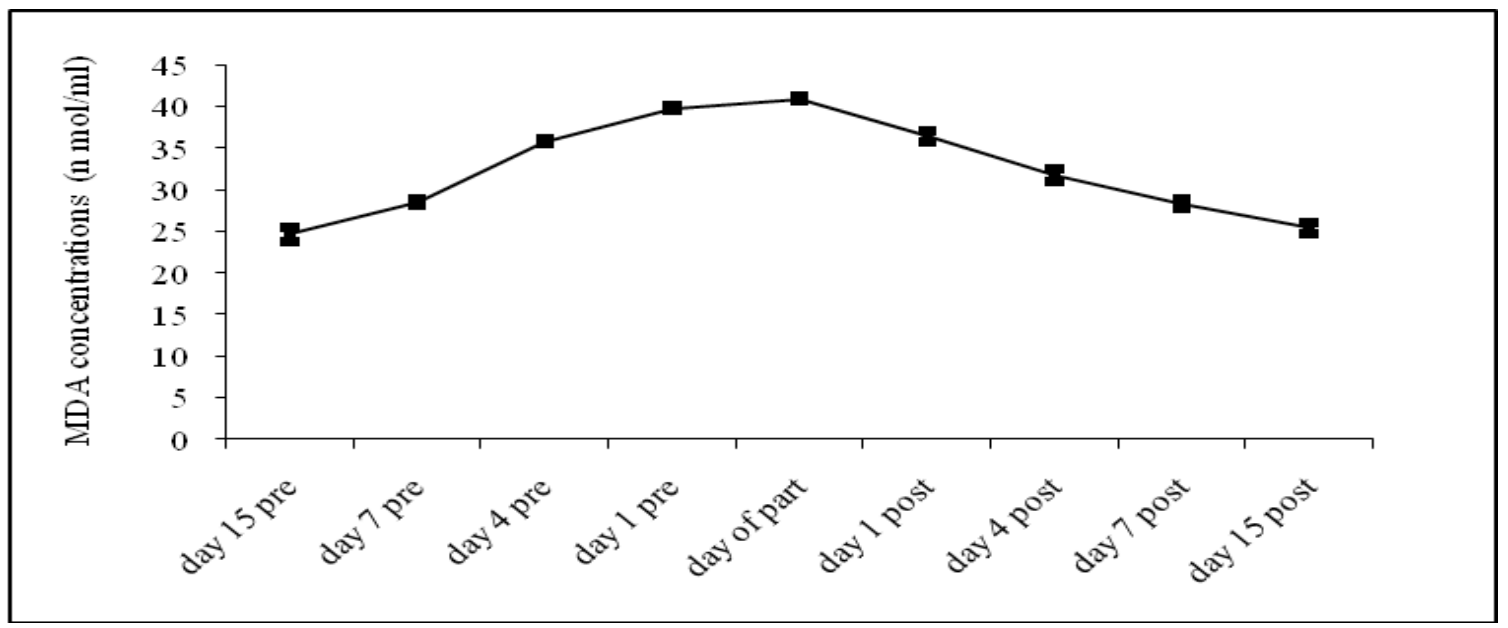

Fig.12. Mean serum MDA concentrations $( \pm \mathrm{SE})$ of pregnant she camels around parturition (pre $=$ prepartum, post=postpartum, day of part=day of parturition).

Egypt. J. Vet. Sci. Vol. 48, No.2 (2017) 


\section{References}

1. Zarrouk, A.,Souilem, O. and Beckers, J.F., Actualitéssur la reproduction chez la femelle dromadaire (Camelus dromedarius). Revue Elev. Med. Vét. Pays Tropi., 56, 95-102 (2003).

2. Alfuraiji, M.M., Concentrations of plasma oestradiol-17 $\beta$, progesterone and cortisol in preand postpartum stages of Arabian she-camel. Arab Gulf Journal of Scientific Research, 16 (1), 173182(1998).

3. Skidmore, J.A., Reproduction in dromedary camels: an update. Animal Reproduction, 2 (3), 161-171 (2005).

4. Aziz Khan, F., Patil, S.K.B. and Thakur, A.S., Lipid profile in thyroid dysfunction. J. Clin. Anal. Med., 5, 12-14 (2014).

5. LaFranchi, S.H., Haddow, J.E. and Hollowell, J.G., Is thyroid inadequacy during gestation a risk factor for adverse pregnancy and developmental outcomes? Thyroid. 15, 60 -71 (2005).

6. Grandon, T., Assessment of stress during handling and transport. J. Anim. Sci., 75, 249-257 (1997).

7. Knowles, T.G., Brown, S.N., Warriss, P.P., Philips, A.J., Dolan, S.K., Hunt, P., Ford, J. E., Edward, J.E., Morton, D. J., Anderson, F., Foggin, G. M., Kock, M. D. and Train, E.P., Plasma cortisol as an indicator of stress due to capture and transportation in wildlife species, Veterinary Record, 136, 60-63 (1995).

8. Warriss, P.D., Brown, S.N., Edward, J.E., Anil, M.H., and Fordham, D.P., Time in lairage needed by pigs to recover from the stress of transport. Vet. Rec., 131, 194-196 (1992).

9. 9. Anderson, D. E., Grubb, T. and Silveira, F., The effect of short duration transportation on serum cortisol response in alpacas (LIama pacos).Vet. J., 157, 189-191 (1999).

10. Riquelme, R.A., LIanos, J.A., McGarrigle, H.H., Sanhueza, E.M. , Hanson, M.A. and Giussani, D.A. Chemo reflex contribution to adrenocortical function during acute hypoxemia in the llama fetus at 0.6 to 0.7 of gestation. Endocrinology. 139, 2567-2570 (1998).

11. Dahlborn, K.,Benlamlih, S.,Zine-Filali, R.,Gueroulali, A, Hossaini-Hilali, J. and Oukessou, M., Food deprivation and refeeding in the camel (Camelus dromedarius). Am. J. Physuiol., 262, 1000-1005(1992).
12. Omidi, A.1., Fathi, M.H. and Asiaban, M., Elevated levels of blood urea nitrogen and creatinine in the last trimester of pregnancy of dromedary camels (Camelus dromedarius) Iranian Journal of Veterinary Medicine (IJVM), 9, (4), 249-255 (2015).

13. Leon, J.B., Smith, B.B., Timm, K.I. and LeCren, G., Endocrine changes during pregnancy, parturition and the early postpartum period in the llama (Lama glama). Journal of Reproduction and Fertility 88, 503-511 (1990).

14. Riveros, J.L., Urquieta, B., Bonacic, C., Hoffmann, B., Bas, F. and Schuler, G., Endocrine changes during pregnancy, parturition and postpartum in guanacos (Lama Guanicoe). Animal Reproduction Science 116, 318-325 (2009).

15. Ross, G.T., Vande Wiele, R. L. and Frantz, A.G., The ovaries and the breasts, In: Williams, R. H., ED., Text book of Endocrinology. Saunders Company, Philadephia, 355 (1981).

16. Wisdom, G. B., Enzyme-immunoassay. Clin. Chem. 22, 1243-1255 (1976).

17. Braverman, L.E., Evaluation Of thyroid status in patients with thyrotoxicosis. Clin. Chem. 42, 174178 (1996).

18. Muzzaffari, E.L. and Gharib, H., Thyroxin suppressive therapy in patients with nodular thyroid disease. Ann. Intern. Med. 128, 386-394 (1998).

19. Burits, C.A. and Ashweed, E.R., Tietz Text book of clinical chemistry, 2 nd Ed. W.B. Saunders Company. Philladdiphia, pp 1825-1827 (1994).

20. 20. Young, D.S., Effects of disease on clinical lab. Tests 4th edition AACC (2001).

21. Koracevic, D. and Koracevic, G .,Total antioxidant capacity (Colorimetric method). J. Clin. Pathol. 54, 356-361 (2001).

22. Harris, L.J., and Ray, S. N., Colorimetric determination of ascorbic acid. LANCET 1, 71, 648-462 (1935).

23. Paglia, D.E. and Valentine, W.N., Studies on the quantitative and qualitative characterization of erythrocyte glutathione peroxidase. J. Lab. Clin. Med. 70,158-169 (1967).

Egypt. J. Vet. Sci. Vol. 48, No.2 (2017) 
24. Ohkawa, H., Ohishi, W. and Yagi, K. Anal. Assay for lipid peroxides in animal tissues by thiobarbituric acid reaction. Biochem, 95, 351 (1975).

25. Snedecor, G.W. and Cochran, W.G., Statistical methods. 7th Edition, the Iowa State University Press, Iowa (1982).

26. El-Mougy, S.A., Heshmet, A., Taha, A. and Ismail, A., Plasma levels of progesterone, total estrogens, prostaglandin $\mathrm{F} 2 \mathrm{a}$, prostaglandin $\mathrm{E}$ and cortisol in one- humped camel (Camelus dromedarius). Egypt. J. Vet. Sci., 21, 79-84 (1984).

27. Shalaby, S.I.A.E., Some studies on the genital organs and blood of the she-camel (Camelus dromedarius). Ph.D. Thesis, Fac. Vet. Med. Cairo University (1986).

28. Agarwal, S.P., Khanna, N.D., Agarwal, V.K. and Dwaraknath, P.K., Circulating levels of estrogen and progesterone in female camels (Camelus dromedarius) during pregnancy. Theriogenology, 28, 849-859 (1987).

29. Adam C.L., Bourke, D.A., Kyle, C.E., Young, P. and Mcevoy, T.G., Ovulation and embryo recovery in the llama. Proc. 1st mt. Camel Conf., 125-127 (1992).

30. Homeida, A.M., Khalil, M.G.R. and Taha, A.A., Plasma concentrations of progesterone, oestrogens, testosterone and LH activity during the estrous cycle in camel (Camelus dromedarius).J. Reprod. Fert., 83, 593-598 (1988).

31. Quzy, I. Anwar Suhel, Purohit, G.N., Hormonal management of ovarian activity in breeding camels two months ahead of the natural breeding season. Camel: An International Journal of Veterinary Sciences, 1, 37- 49 (2013).

32. Skidmore, L., Reproductive Physiology in the Female Camel. Pregnancy. In: Lecture Notes for the Short Course in Reproduction in the Dromedary Camel. Publisher: International Veterinary Information Service, Ithaca, New York, USA (2004).

33. Elias, E., Bedrak, E. and Yagil, R., Estradiol concentration in the serum of the one humped camel during the various reproductive stages. General and comparative. Endocrinology, 53, 235 (1984).

34. Mohamed, W.S., Studies on changes of progesterone and estrogen level together with some trace elements in pregnant she camel. M.V. Sc. thesis, Cairo Univ., Egypt (1991).

35. Hassan, M.S., Ghoneim, I.M. and kariman D. Hassanin., Hormonal changes during pregnancy and postpartum period in she camels. Eighth
Annual congress Egypt .Soc. Anim. Reprod. Fret. January 18- 20 (1996).

36. El-Wishy, A.B., Hemeida, N.A., Omar, M.A., Mobarak, A.M. and ElSayed, M.A., Functional changes in the pregnant camel with special reference to fetal growth. British Veterinary Journal, 137, 527- 537 (1981).

37. Wilson, R.T., The Camel. Longman, London. p. 15 (1984).

38. 38. Anderson, A.B.M., Flint, A.P.F. and Turnbul, A. C., Mechanism of action of glucocorticoids in induction of ovine parturition effect on placental steroid metabolism. J. Endocrinol., 66, 61-70 (1975).

39. Steel, P. A., Flint, A.P.F. and Turnbull, A.C. Activity of steroid C17, 20 lyase in the ovine placenta: effect of exposure to fetal glucocorticoid. J. Endocrinol. 69, 239 - 246 (1976).

40. Khan, J.R. and Ludri, R.S., Hormone profile of crossbred goats during the periparturient period. Tropical Animal Health and Production, 34, 151162 (2002).

41. Alwan AF, Amin FAM and Ibrahim NS. Blood progesterone and oestrogen hormones level during pregnancy and after birth in Iraqi sheep and goat Basrah Journal of Veterinary Research, 10, 153 (2010).

42. Habeeb, A.A.M., Abdel-Samee, A.M. and Aboulnaga A. I., Blood biochemical and hormonal changes in female dromedary camels in relation to pregnancy stage and parity number. Egyptian $J$. Appl. Sci., 17, 389-404 (2002).

43. Rhodes, R.C., The Physiology of Gestation and Parturition. University of Rhode Island, in cooperation with the U.S. Department of Agriculture Extension Service, West Virginia University (2003).

44. Arthur G.H., Noakes, D.E. and Pearson, H., Veterinary Reproduction and Obstetrics, $6^{\text {th }} \mathrm{ed}$, ELBS Publishers, London, UK. pp 133 (1989).

45. Suganya, G., Leela, V., Viswanathan, S. and David, B.P., Circulating levels of cortisol during pregnancy, parturition and postpartum periods in goats. Indian Veterinary Journal, 77, 202-204 (2000).

46. Suganya, G. and Gomathy, V.S., Hormone profile of Tellicherry goats during periparturient period. Tamilnadu. Journal of Veterinary and Animal Sciences 5, 211-221 (2009).

47. Thorburn, G.D., Challis, J.R.C. and Currie, W.B., Control of parturition in domestic animals. Biol. Reprod., 16, 18 - 27 (1977). 
48. Shukla, S.P., Pandey, A. and Nema, S.P., Emergency induction of parturition in buffaloes. Buff. Bull., 27,148-149 (2008).

49. Bell, A.W., Regulation of organic nutrient metabolism during transition from late pregnancy to early lactation. J. Anim. Sci., 73, 2804- 2819 (1995).

50. Rahman, H., Ara Chowdhury, M. and Towhidul Alam, M., Serum thyroxine and triiodothyronine levels in normal pregnancy and pre-eclampsia. $J$. Teach. Assoc., 20, 6-10 (2007).

51. Duntas, L. H., Thyroid disease and lipids. Thyroid.12, 287-293 (2002).

52. Leung, A. M. and Farwell, A. P., Thyroid function testing in ambulatory practice, In Thyroid Function testing, edited by G. A. Brent, Volume 28 of Thyroid Function Testing: 155171. Springer US (2010).

53. Agarwal, S. P., N. D Khanna, V. K. Agarwal, and P. K. Dwaraknath., Circulating concentrations of thyroid hormones in pregnant camels (Camelus dromedarius). Theriogenology, 31, 1239-1247 (1989).

54. Pichaicharnarong, A.A., Loypetjra, P., Chaiyabutr, N., Usanakornkul, S. and Djurdjevic, D.J., Thyroid activities of non-pregnant, pregnant, postpartum and newborn swamp buffaloes. J. Agric. Sci., 98, 483-486 (1982).

55. Mehta, J.S., Bhatia, I.S., Kohli, L.S., Pareek, P.K., Bshnoi, B.L. and Gupta, A.K., Studies on serum alkaline phosphatase and protein in various reproductive states in cow. Indian J Anim. Res., 10 (2), 138-140 (1989).

56. Nath, H.C., Baruah, K.K.,Baruah, A., Sarmah, H.D. and Sarmah, B.C., Serum cholesterol and protein in pre, peri and postpartum cows. Indian Vet J., 82, 519-521 (2005).

57. Ghanem, M.M., Mahmoud, M.E., Abd El-Raof, Y.M. and El-Attar, H.M., Metabolic profile test for monitoring the clinical, hematological and biochemical alterations in cattle during periparturient period, Benha Vet. Med. J., 23, (2), 13-23 (2012).

58. Batavani, R.A., Ansari, M.H. and Asri, S., Concentration of serum total protein and protein fractions during diestrus and pregnancy in Makuii ewes. Comp Clin Path., 5(4), 227-230 (2006).

59. Kaushik, H.K. and Bugalia, N.S., Plasma total protein, cholesterol, minerals and transaminase during pregnancy in goats. Indian Vet. J., 76, 603-606 (1999).

60. Hang-Poung, F., The relationship between the seasonal serum biochemical profile and reproductive performance in perinatal Holstein cows. Taiwan J Vet Med Anim. Husb.54, 1-19(1989).

61. Saleh, M.A., El-Sokkary, G.H. and AbdelRazik, A.R., Circulating steroids and proteins in Egyptian oasis pregnant camels (Camelus dromedaries). J. Camel Pract. Res. 7(1), 9-13(2000).

62. Jainudee, M.R. and Hafez, E.S.E., Gestation Prenatal Physiology and Parturition. In, Hafez ESE (Ed): Reproduction in Farm Animals. Lea and Febiger, Philadelphia. pp. 247-283 (1994).

63. Janku, L., Pavlata, L., Mišurová, L., Filípek, J., Pechová, A. and Dvořák, R., Levels of protein fractions in blood serum of periparturient goats. Acta Vet. Brno., 80, 185-190 (2011).

64. Kupczynskir, and Chudoba-D rozdowska. Values of selected biochemical parameters of cows'blood during their drying-off and the beginning of lactation. Electr. J. Pol. Agr. Univ. Vet. Med., Vol. 5 Issue 1(2002).

65. Eltohamy, M.M., Salama, A. and Yousef, A.A., Blood glucose in relation to the reproductive state in she-camel (Camelus dromedaries). Beitr Trop Landwirtsch Veterinarmed, 24 (4), 425-430 (1986).

66. Brzezinska, S. E., Miller, J. K., Qigley, J. D. and Moore, J. R., Antioxidant status of dairy cows supplemented prepartum with vitamin $\mathrm{E}$ and selenium. J. Dairy Sci., 77, 3037-3095 (1994).

67. Panda, N. and Kaur, H., Effect of supplemental vitamin $\mathrm{E}$ on plasma total antioxidant activity in periparturient Murrah buffaloes. Proc. 4th Asian Buffalo Congress p180. Feb. 25-28, New Delhi (2003).

68. Panda N, H. Kaur and Mohanty, T. K., Reproductive Performance of Dairy Buffaloes Supplemented with Varying Levels of Vitamin E. Asian-Aust. J. Anim. Sci., 19 (1), 19-25 (2006).

69. Sharma, N., Singh, N. K., Singh, O. P., Pandey, V. and Verma, P. K., Oxidative Stress and Antioxidant Status during Transition Period in Dairy Cows Asian-Aust. J. Anim. Sci., 24 (4), 479-484 (2011).

70. Gitto, E., Reiter, R. J., Karbownik, M., Tan, D. X., Gitto, P., Barberi, S. and Barberi, I., Causes of oxidative stress in the pre- and perinatal period. Biol. Neonate, 81, 146-157 (2002).

71. Bernabucci, U., Ronchi, B.,Lacetera, N. and Nardone, A., Influence of body condition score on relationships between metabolic status and oxidative stress in periparturient dairy cows. $J$. Dairy Sci., 88, 2017- 2026 (2005).

Egypt. J. Vet. Sci. Vol. 48, No.2 (2017) 
72. Sordillo, L. M., O Boyle, N., Gandy, J.C., CORL, C.M. and Hamilton, E., Shifts in thioredoxin reductase activity and oxidant status in mononuclear cells obtained from transition dairy cattle. J. Dairy Sci., 90, 1186- 1192 (2007).

73. Hasab E. Mohamed, Ahmed Alhaidary and Anton C. Beynen., Ascorbic acid status of female camels during different phases of reproduction Trop Anim. Health Prod., 43, 279-281 (2011).

74. Miszkiel, G., Skarzynski, D.,Bogacki, M. and Kotwica, J., Concentrations of catecholamine, ascorbic acid, progesterone and oxytocin in the corpora lutea of cyclic and pregnant cattle. Reproduction Nutrition and Development, 39, 509 - 516(1999).

75. Naziroğlu, M. and Gür, S., Antioxidants and lipid peroxidation levels of blood and cervical mucus in cows in relation to pregnancy. Deutsche Tierärztliche Wochenschrift, 107, 374 -376(2000).

76. Scott, W., Lipid peroxidation in pregnancy. Hypertension in pregnancy.13(1), 1-32(1994)

77. Patil, S.B., Kdliwad math, M.V. and Kodliwad math, S.M., Study of oxidative stress and enzymatic antioxidants in normal pregnancy. Indian Clin. Biochem. 22(1), 135 - 137(2007).
78. Wickens, D., Oxidation (peroxidation) products in plasma in normal and abnormal pregnancy. Lancet, 343, 511-514 (1981).

79. Cederbery, J., Oxidative stress ant oxidative defenses and outcome of gestation in experimental diabetes pregnancy. M. Sc. Sci. Thesis, Uppsala UN Sweden (2001).

(Received 11/11/ 2017; accepted 20/12/ 2017)

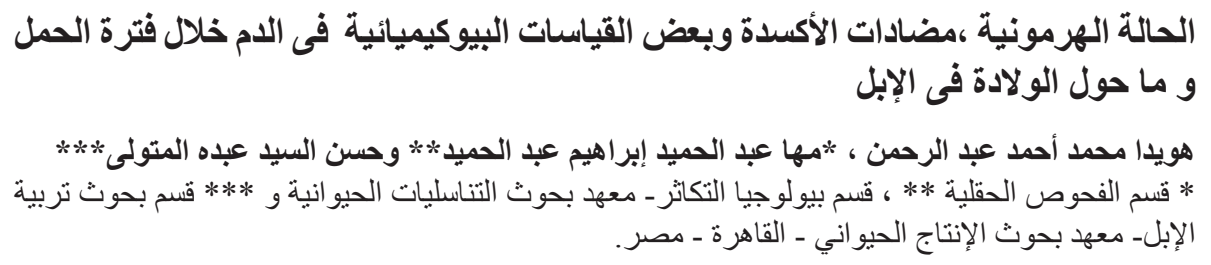

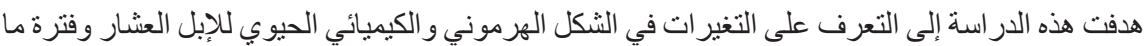

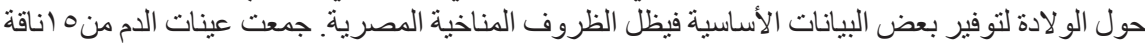

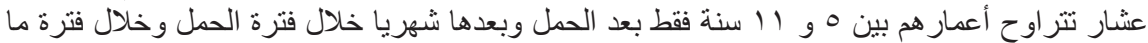

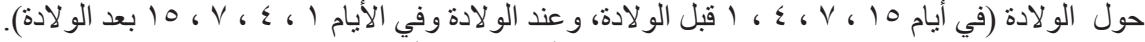

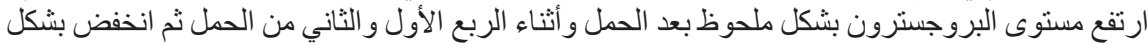

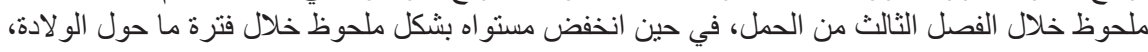

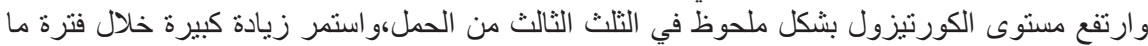

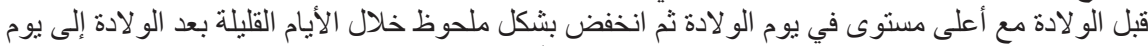

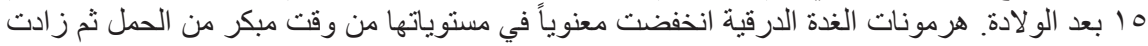

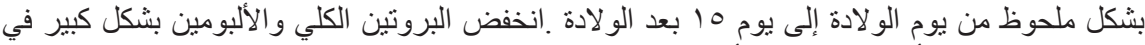

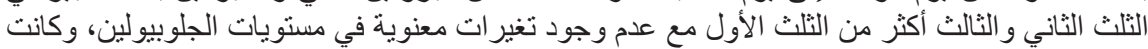

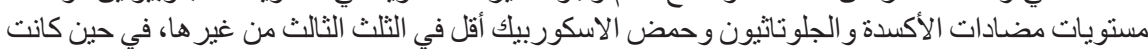

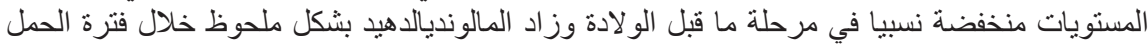

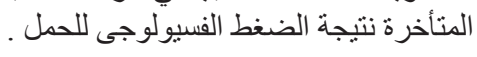

كلمات البحث: هرمونات الحمل ،كيمياء الدم ،مضادات الأكسدة، إناث الإبل.

Egypt. J. Vet. Sci. Vol. 48, No.2 (2017) 